\title{
Alterations in the thermogenetic mechanism during postnatal development: the dependence on environmental temperature conditions ${ }^{1}$
}

\author{
Kurt BrüCK and Barbara WüNNENBERG \\ Physiologisches Institut der Universität Marburg, Marburg
}

\begin{abstract}
KURZFASSUNG: Veränderungen im thermogenetischen Mechanismus während der postnatalen Entwicklung: die Abhängigkeit von Umwelttemperaturbedingungen. Es werden zwei Modi der Thermogenese untershieden: Muskelzittern und non-shivering Thermogenese (NST; chemische Thermogenese im eigentlichen Sinne). Der letztere Mechanismus ist stärker ausgeprägt bei kälteadaptierten Nagern und bei Neugeborenen zahlreicher Species, so auch beim menschlichen Neugeborenen. Ein für die NST bedeutsames Gewebe stellt das multiloculäre Fettgewebe („braunes“ Fettgewebe) dar. Untersuchungen zur Bestimmung der quantitativen Anteile der beiden Modi der Thermogenese im Verlaufe der Entwicklung des neugeborenen Meerschweinchens haben zu folgenden Ergebnissen geführt: (1) Bei einer Testtemperatur von $8^{\circ} \mathrm{C}$ beträgt der Anteil der NST beim neugeborenen Tier $90 \%$ der Gesamtthermogenese; letztere beträgt das 3- bis 4 fache des Grundumsatzes und reicht aus, um die Rectaltemperatur der Tiere auf $39^{\circ} \mathrm{C}$ zu halten. Nadı Blockade der NST tritt kräftiges Kältezittern auf: der Mechanismus des Kältezitterns ist ausgebildet, wird aber normalerweise nicht eingesetzt. Die Wärmebildungskapazität des non-shivering Mechanismus ist wesentlich größer als die des Kältezitterns. (2) Im Alter von 4 Wochen macht bei in Wärme aufgezogenen Tieren $\left(30^{\circ} \mathrm{C}\right)$ der Anteil der NST nur noch weniger als 10 bis $15 \%$ aus, bei Tieren, die in Kälte $\left(8^{0} \mathrm{C}\right)$ gehalten worden waren, jedoch noch $50 \%$. (3) Beim neugeborenen Tier beträgt der Anteil allein des interscapularen multiloculären Fettgewebes über 2\% der Körpermasse. Bei den in Kälte aufgezogenen Tieren bleibt die multiloculäre Struktur dieses Gewebes erhalten, die Masse des Gewebes fällt jedoch auf 0,7\% ab. Bei Aufzucht in Wärme erfährt das interscapulare Fettgewebe innerhalb von 2 bis 4 Wochen eine vollständige Umwandlung in weißes Fettgewebe. Der Abbau der NST ist somit als Entwicklungsprozeß anzusehen, der durch niedere Umgebungstemperatur hintangehalten, aber nicht vollständig aufgehalten werden kann.
\end{abstract}

\section{INTRODUCTION}

For a long time temperature control of the neonate was thought to be characterized essentially by shortcomings when compared with the adult system. During the last few years it has become evident, however, that the temperature control system is - depending on the species - more or less completely adjusted to the relatively large 184/4).

1 This investigation was supported by the Deutsche Forschungsgemeinschaft (GraNT 
heat loss due to the smaller body size of the neonate. The most important factor in this adjustment is to be seen in the prevalence of non-shivering thermogenesis, the heatforming capacity of which has been shown to be larger than that of the shivering mechanism (BRÜcK 1964, 1965b). That shivering or voluntary movements cannot account for the cold-induced heat production in the newborn infant has been already inferred from earlier studies (BRücK 1961, BRÜCK et al. 1958, MordHorsT 1933). Further evidence on the existence of non-shivering thermogenesis in the neonate has been obtained from a number of studies in newborn mammals (BRück 1963, Dawkins \& Hull 1964, Dawkins \& Scopes 1965, Moore \& Underwood 1962, 1963; SCOpes \& Tizard 1963), and in the newborn infant (DAwkrns \& SCOpes 1965, Karlberg, Moore \& Oliver 1962).

It has been further shown that the multilocular adipose tissue ("brown fat"), whose thermogenetic function was first demonstrated in the hibernator (SMITH \& Hock 1962), also plays an important part in the neonate as a site of non-shivering thermogenesis (DAwkINS \& Hulc 1964, DAwKINS \& SCOPEs 1965).

With regard to the prevalence of non-shivering thermogenesis, temperature regulation of the neonate resembles that of the cold-adapted adult rat (cf. HART, Heroux \& Decopas 1965, Hsieh, Carlson \& Gray 1957). It might appear from this fact, that the modifications occuring during cold-adaptation are, in some respect at least, to be thought of as a remanifestation of the neonatal thermoregulatory mechanism. From this point of view, the question arises at which period of postnatal development and under what conditions the non-shivering mechanism is replaced by shivering; further, whether or to what extent it is possible, by providing special environmental conditions, to maintain the prevalence of non-shivering thermogenesis.

To answer these questions, studies have been carried out in guinea pigs from birth on. Some of these results have been already published (BRücK 1963, BRüCK \& WüNNENBERG $1965 \mathrm{a}, \mathrm{b}, \mathrm{c}$ ) and will be briefly reviewed. The remaining data, which have been obtained only recently from two groups of animals that were reared at two different environmental temperatures $\left(30^{\circ}\right.$ and $8^{\circ} \mathrm{C}$, respectively), will be reported in detail.

\section{METHODS}

For the examination of thermoregulatory behavior, the individual unanesthetized guinea pigs were placed in a small climatized plexiglass chamber, the temperature of which could be quickly altered within the range of $35^{\circ}$ and $8^{\circ} \mathrm{C}$. In most experiments the animals were consecutively exposed to three test temperatures: $30^{\circ}$ to $32^{\circ}, 16^{\circ}$ and $8^{\circ} \mathrm{C}$.

For the determination of gaseous metabolism, the open-system method was used: Fresh air was passed through the chamber and led to a gas-analyzer (Manufactured by Hartmann \& Braun AG, Frankfurt/M., W.-Germany). Oxygen uptake, $\mathrm{CO}_{2^{-}}$ production, chamber temperature, subcutaneous temperature on the back and the temperature of the interscapular fat pad were continuously recorded. Further, the electrical activity of the thigh and neck musculature was recorded as a measure of shivering. 
For the determination of electrical activity, small electrode units were inserted into the respective muscle groups through a small incision in the skin and were fixed with thread. The discharges were displayed on the two doublebeam oscilloscopes of an EMG-Integrator (Manufactured by Dr. Tönnies, Freiburg/Br., W.-Germany). The second beam of each screen was used to depict the automatically produced product of the amplitudes and frequency of the volleys. The activity was continuously observed and recorded at intervals of 2 to 5 minutes. By planimetry of the curves representing the product of amplitudes and frequency, the mean electrical activity was determined for one-minute periods.

Alderlin (2-isopropylamino-1-[2-naphthyl] ethanol hydrochloride, an adrenergic beta-receptor-blocking compound, was used to block selectively non-shivering thermogenesis (cf. BRÜcK \& WÜNNENBERG 1965b). During this blockade it was possible to determine the relationship between oxygen uptake and electrical activity. On this basis the fractions of shivering and non-shivering thermogenesis could be estimated in untreated animals from the electrical activity and total cold-induced oxygen uptake.

For the test studies the animals were fixed on a plate with strings bound around the distal parts of the four extremities in order to prevent the animals from nibbling the leads of the thermocouples, etc. Due to this measure, heat loss in the animals was somewhat larger than it would have been under natural conditions, since they could not sufficiently reduce their body surface by retracting their legs.

It should also be mentioned that while the electrodes, etc. were being inserted, the animals were kept under light ether anesthesia. The test study was not commenced, however, until the effect of this anesthesia had vanished. (For further details of the methods see BRück \& WüNNENBERG 1965a, b, c.)

\section{RESULTS}

Thermogenesis in newbornguinea pigs reared at 16 to $19^{\circ} \mathrm{C}$

At a test temperature of $8^{\circ} \mathrm{C}$ oxygen uptake of a group of newborn guinea pigs ( 0 to 2 days of age) has been found to increase up to 70 to $90 \mathrm{~m} / / \mathrm{kg} \mathrm{min}$, i. e. 3 to 4 times the basal metabolic rate, which is approximately $20 \mathrm{ml} / \mathrm{kg} \min$ (BRück \& WüNNENBERG 1965a). Under these conditions, the electrical activity of the musculature remained at zero level or was only slightly increased. In contrast, a group of animals two to three weeks of age displayed overt shivering, and the electrical activity of the musculature was markedly increased. The occurrence of shivering, however, did not increase the thermoregulatory efficiency; i. e. regardless of the increased electrical activity, oxygen uptake did not exceed $50 \mathrm{ml} / \mathrm{kg}$ min. It was concluded from this that the contribution of non-shivering thermogenesis is considerably reduced during the first few weeks of life.

Effects of Alderlin. Oxygen uptake as measured at the test temperatures of $8^{\circ}$ or $16^{\circ} \mathrm{C}$ decreased from 70 to 90 to about $40 \mathrm{ml} / \mathrm{kg}$ min in newborn guinea pigs 
following Alderlin administered intraperitoneally at a dose rate of $10 \mathrm{mg} / \mathrm{kg}$. This effect was accompanied by a sharp increase in electrical activity and by onset of overt shivering, demonstrating that the mechanism of shivering is already developed at the time of birth but is not used under normal conditions. In the older animals ( 2 to 3 weeks of age), which displayed normally overt shivering, electrical activity was not essentially altered by Alderlin, and oxygen uptake was reduced by no more than 10 to $15 \mathrm{ml} / \mathrm{kg}$ min. The level of oxygen uptake attained following the application of Alderlin was of the same order as that in the newborn group. By quantitative consideration of the electrical activity ( $c f$. methods), it was estimated from these figures that the contribution of non-shivering thermogenesis to the total cold-induced heat production is reduced from 90 to $30 \%$ during the first few weeks of life, if the animals are reared under usual environmental conditions. It can further be deduced from these studies that the heat-forming capacity of the shivering mechanism is much less than that of the non-shivering mechanism which it replaces (BRÜCK \& WÜNNENBERG 1965b).

Changes of structure and thermogenetic function of the interscapular adipose tissue. In the group of newborn animals the typical multilocular fat distribution could be demonstrated, whereas unilocular fat distribution was found to prevail in the older animals (2 to 3 weeks). To obtain insight into the thermogenetic function of this tissue, local temperature of the interscapular fat pad (Dawkins \& Hull 1964, 1965; SMITH \& Hock 1962) and local blood flow (using the heated thermocouple technique; cf. GolenHofen, Hensel $\&$ HILDEBRANDT 1963) were measured. In newborn animals the temperature of the fat pad rose over the colon temperature (by $1^{0}$ to $1.5^{\circ} \mathrm{C}$ ), and blood flow was markedly increased when the animals were exposed to the test temperatures of $16^{\circ}$ or $8^{\circ} \mathrm{C}$. In some cases, even an absolute increase in temperature occurred. These effects were inhibited by Alderlin. By contrast, in the animals two to three weeks of age, the temperature of the fat pad paralleled that of the colon, and Alderlin did not appreciably change this course. These findings indicate that, on cooling, extra-heat is produced in the multilocular adipose tissue of the newborn guinea pig; this agrees well with the concept of SMITH \& ROBERTS (1964), according to which the multilocular adipose tissue is an important site of non-shivering thermogenesis, and with the results obtained from the newborn rabbit by DAwKINS \& HULL $(1963,1964)$.

\section{The influence of environmental temperatures on postnatal alterations in thermogenesis}

In Table 1 the number, mean birth weight, and actual weight of the animals at the date of the studies are listed. Except for two 4-hour periods daily, each litter reared at $8^{\circ} \mathrm{C}$ was kept together with its mother in one cage, in order to provide sufficient nourishment for the young. The animals reared at $32^{\circ} \mathrm{C}$ were left with their mother all the time. The weight gain of a few animals (not included in the present study), which were tentatively held at $4^{\circ} \mathrm{C}$, was markedly retarded, and thermo- 
regulatory behavior was disturbed. This is considered to show that the cold stress imposed on the experimental group of animals was near the tolerance limit.

Two-thirds of the animals were examined at the age of two weeks, the rest at the age of four weeks. Figure 1 compares the responses of two animals that were reared at the two different environmental temperatures. In the $8^{0}$-animal slight cooling caused oxygen uptake to increase by ca. $18 \mathrm{ml} / \mathrm{kg}$ min without an appreciable increase in electrical activity. It was only after further cooling that the electrical activity rose (accompanied by visible shivering); this caused oxygen uptake to increase further until a level of about $65 \mathrm{ml} / \mathrm{kg}$ min was attained. The animal was

Table 1

Data on the guinea pigs used in the present study

\begin{tabular}{|ccccc|}
\hline $\begin{array}{c}\text { Number of } \\
\text { animals }\end{array}$ & $\begin{array}{c}\text { Reared } \\
\text { at } \\
\left({ }^{\circ} \mathrm{C}\right)\end{array}$ & $\begin{array}{c}\text { Studied at the } \\
\text { age } \\
\text { (weeks) }\end{array}$ & $\begin{array}{c}\text { Mean } \\
\text { birthweight } \\
\text { (g) }\end{array}$ & $\begin{array}{c}\text { Mean weight at } \\
\text { the date of } \\
\text { examination } \\
\text { (g) }\end{array}$ \\
\hline 10 & 8 & 2 & 90,0 & 159,9 \\
7 & 8 & 4 & 89,9 & 229,6 \\
10 & $30-32$ & 2 & 95,5 & 160,3 \\
4 & $30-32$ & 4 & 92,2 & 246,4 \\
\hline
\end{tabular}

rewarmed, and the experiment was repeated after application of Alderlin. Here, electrical activity and oxygen uptake increased simultaneously, and the maximum oxygen uptake did not exceed $48 \mathrm{ml} / \mathrm{kg}$ min. The fraction of non-shivering thermogenesis, which can be easily read from this curve, is indicated by the double arrows. In the $32^{0}$-animal (Fig. 1, right) Alderlin did not have any effect on the course of oxygen uptake or on electrical activity: Prior to and following Alderlin the rise of oxygen consumption did not commence until the electrical activity was increased. The maximum oxygen uptake was no higher in this case than in the cold animal after the application of Alderlin. Evidently, the mechanism of non-shivering thermogenesis was still functioning in the cold animal, whereas it had vanished in the warm animal.

For the determination of the average fraction of non-shivering thermogenesis, the 10-minute means of oxygen uptake and the corresponding electrical activity (the values from the two muscle groups being added), as measured a $\mathrm{t}$ e $\mathrm{r}$ administration of Alderlin, have been separately plotted for the four groups; these were arranged according to age and the temperature at which they were reared (Fig. 2). The regression lines calculated from these figures represent oxygen uptake as a function of electrical activity. The average oxygen uptake and electrical activity, as calculated from the values which were obtained from those test periods that preceded the administration of Alderlin, were also plotted in the diagrams. As can be seen in Figure 2, the values obtained from the untreated animals are situated to the left and above the regression lines in the $8^{\circ} \mathrm{C}$-animals, but they come close to the regression lines in the warm animals. The amount of oxygen uptake which is not explained by electrical activity, i. e. non-shivering thermogenesis by definition, can be directly read from these diagrams. 
Postnatal alterations in the thermogenetic mechanism

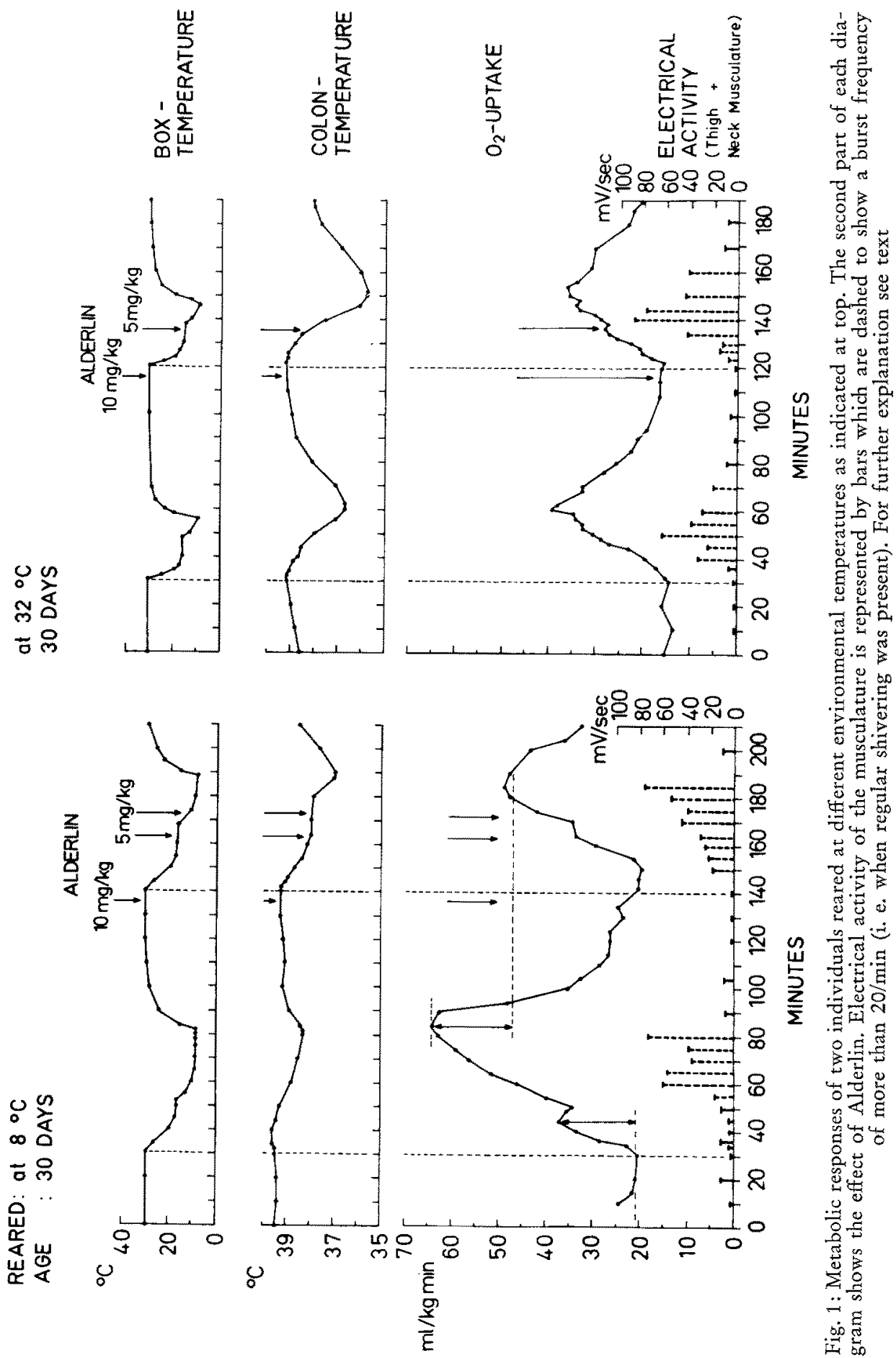


The fractions of shivering and non-shivering thermogenesis as determined in this way can be taken from Figure 3. For comparison, the corresponding data for a group of newborn animals have been included. As can be easily seen, the cold animals had preserved a considerable amount of non-shivering thermogenesis, although it was

\section{REARED}

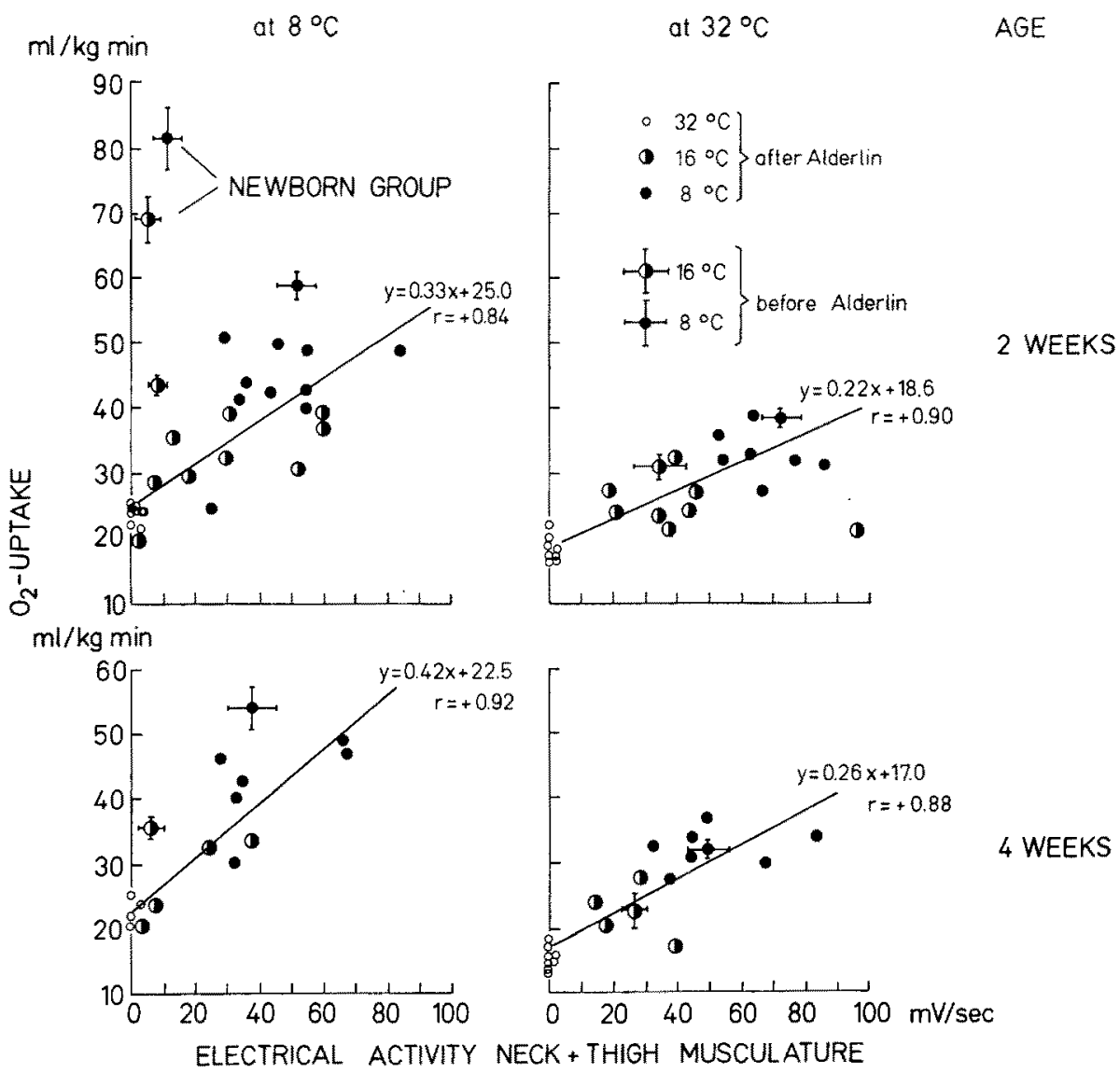

Fig. 2: Oxygen uptake and electrical activity in four groups of guinea pigs arranged according to age and the temperature at which they were reared. The dots represent the values of individual animals that were examined under the influence of Alderlin; the dots with bars stand for the group means obtained from studies that were carried out prior to Alderlin application. The length of the bars indicates S. E. In addition, the mean values of a group of newborn animals are plotted. The amount of oxygen uptake that is not explained by electrical activity can be directly read from the diagrams

reduced in comparison with the newborn group. Non-shivering thermogenesis was just sufficient to compensate for the heat loss at $16^{\circ} \mathrm{C}$, but it was too small for the $8^{\circ} \mathrm{C}$ temperature, at which non-shivering thermogenesis accounted for only $50 \%$ of the total thermogenesis. In the $\mathrm{w}$ a $\mathrm{m}$ animals, non-shivering thermogenesis made up 
only a small fraction of total cold-induced oxygen uptake at the age of two weeks, and it had almost totally vanished by the age of four weeks.

Figure 4 shows the course of three temperatures during the initial phase of cooling in warm and cold animals at the age of 2 weeks. The increase in the temperature of the interscapular fat tissue over colon temperature shows that the thermogenetic function of this tissue had been maintained in the cold animals. In the warm animals, fat temperature dropped together with the colon temperature, indicating that the

Cold-induced oxygen consumption
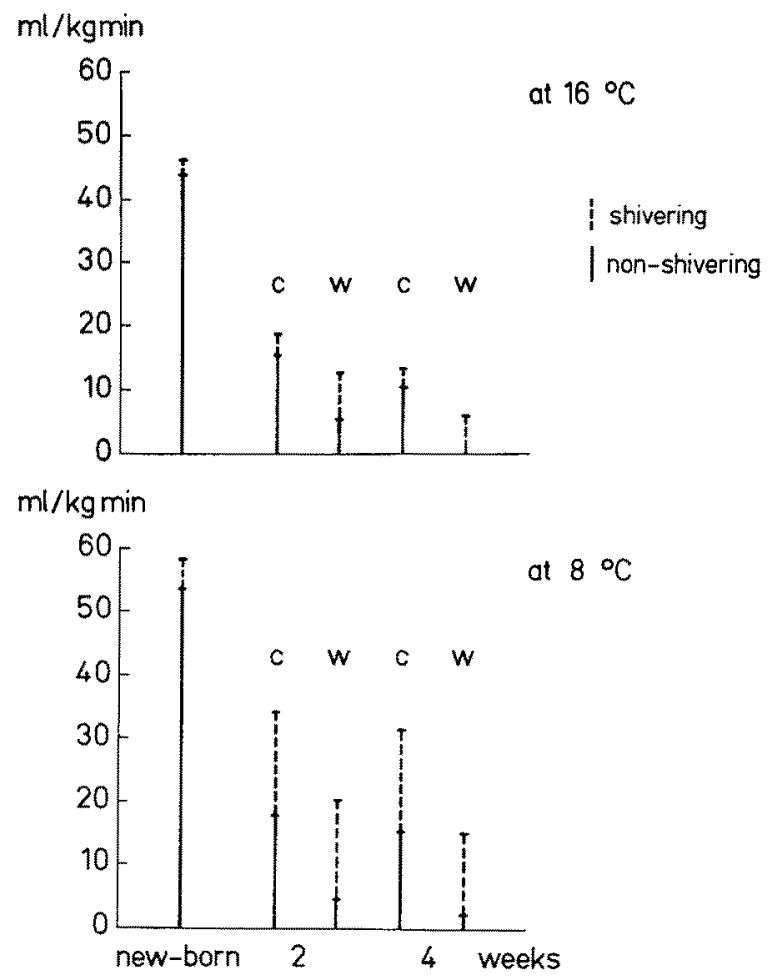

Fig. 3: Shivering and non-shivering thermogenetic capacity, related to age and the temperature at which the guinea pigs were reared

thermogenetic function of this tissue was already reduced at the age of two weeks; this agrees well with the results demonstrated in Figures 2 and 3. Following the injection of Alderlin, fat temperature dropped parallel with the colon temperature in both warm and cold animals.

Microscopic studies on the interscapular fat tissue are in agreement with the above results (Fig. 5). The multilocular fat distribution, which is characteristic for the newborn stage, was maintained in the cold animals; in the warm animals, however, unilocular fat distribution was prevalent at the age of 2 weeks, and at the age of four weeks practically no multilocular fat distribution was demonstrable, i. e. the 
"brown" fat had been entirely converted into "white" fat. Dr. HoHorst and coworkers of the Department of Biochemistry of the University of Marburg, who are working on the metabolism and enzyme pattern of brown adipose tissue, have done some biochemical studies on the interscapular tissue that was taken from our animals. They have kindly permitted us to mention these unpublished data: The content of extractible proteins ( $a$ measure for the total enzyme content) amounted to $55 \mathrm{mg} / \mathrm{g}$

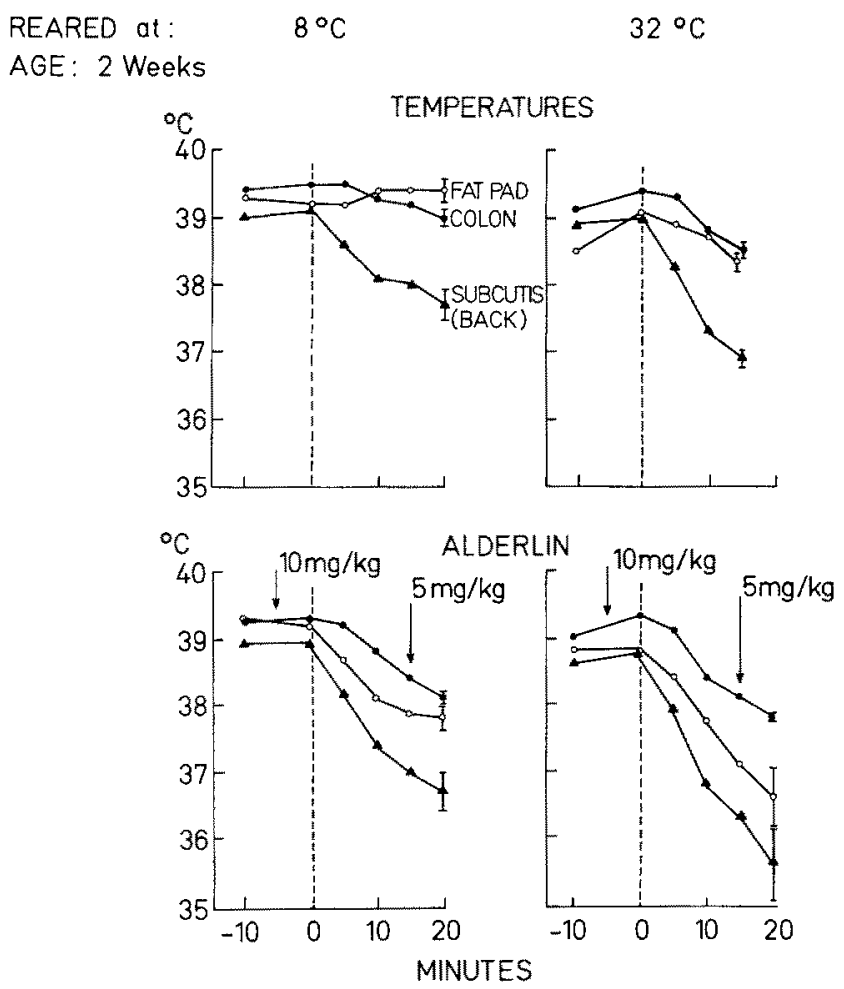

Fig. 4: Course of colon, subcutis and interscapular adipose tissue temperature during cooling, prior to and following the administration of Alderlin. The guinea pigs were exposed to $30^{\circ} \mathrm{C}$ till zero time, at which temperature was decreased to $16^{\circ} \mathrm{C}$. Note that the temperature of the adipose tissue increases over colon temperature in the animals reared at $8^{\circ} \mathrm{C}$

wet weight in the group of newborn animals; in the cold animals this amount was unchanged, but it was reduced to about $25 \mathrm{mg} / \mathrm{g}$ wet weight in a group of animals reared at $18^{\circ}$ to $19^{\circ} \mathrm{C}$ at the age of 20 days ( $20 \mathrm{~d}$-animals). The cytochrome-c content in the cold animals was 4 to 5 times, and the content of the $\alpha$-glycero-phosphateoxydase 4 times that of the $20 \mathrm{~d}$-animals. These data demonstrate the increased mitochondrial activity in the multilocular adipose tissue.

The weight of the interscapular tissue per $100 \mathrm{~g}$ of body weight amounted to $0.70 \mathrm{~g}$ (S. E. 0.05) in the cold animals; this is much less than in newborn guinea pigs (2.1 to $2.4 \mathrm{~g}$ ) and in newborn rabbits (DAwkrNs \& Hull 1963). In the warm animals, 

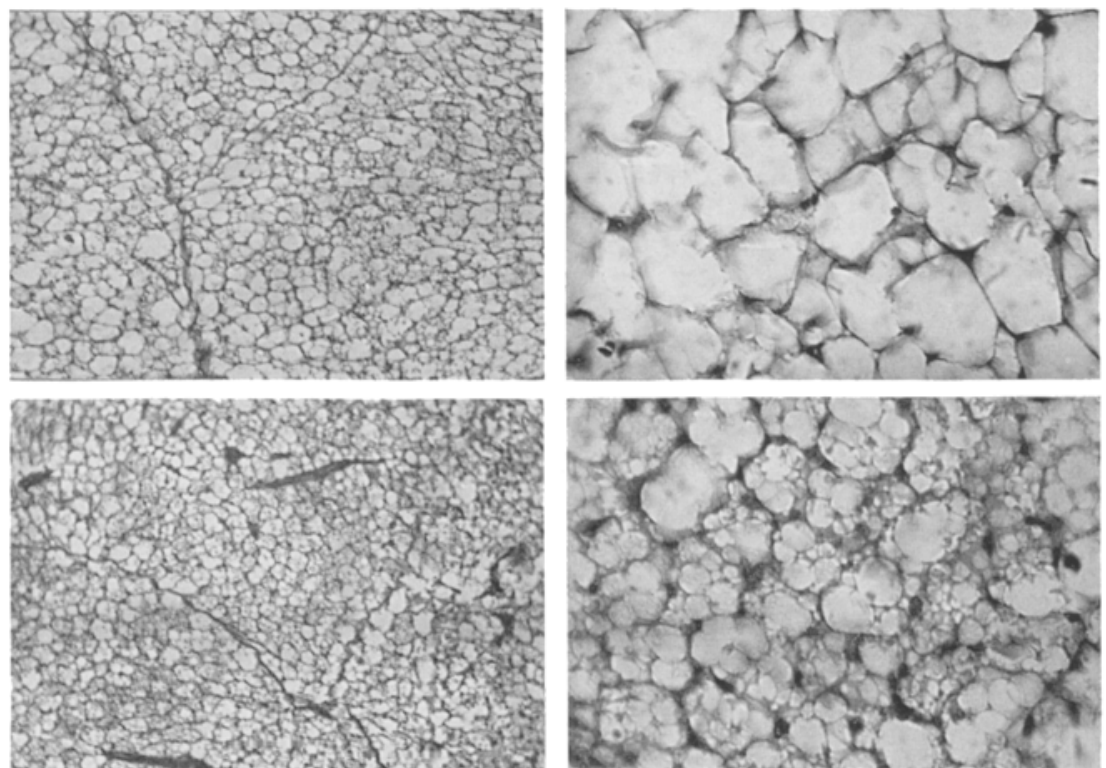

Age: 2 weeks
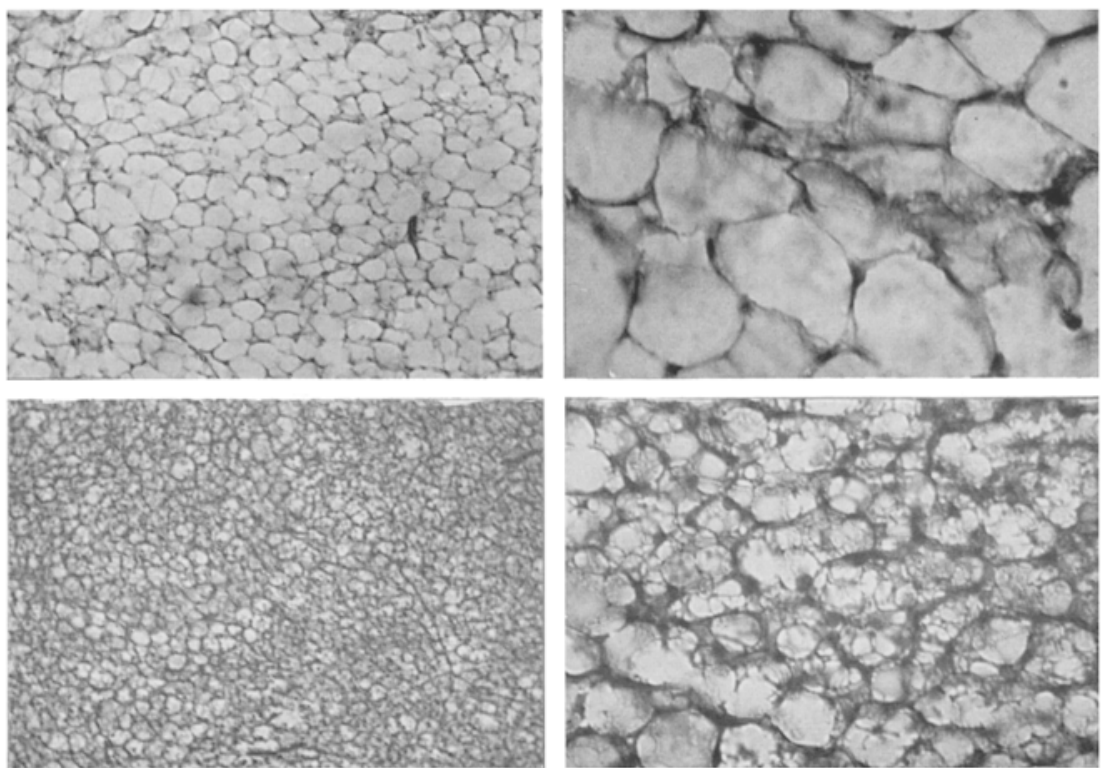

Age: 4 weeks

Fig. 5: Interscapular adipose tissue of 4 guinea pigs, sacrificed at the age of 2 and 4 weeks, respectively. As indicated on the right the animals had been reared at $32^{\circ}$ and $8^{\circ} \mathrm{C}$, respectively. Stained by Hematoxylin-Eosin 
the weight was surprisingly greater $(1.40 \mathrm{~g}, \mathrm{~S}$. E. 0.05$)$, but this is not at variance with the above results, since it consisted of cells with unilocular fat distribution.

\section{DISCUSSION AND CONCLUSIONS}

It follows from the results presented that non-shivering thermogenesis, which is the prevailing mechanism of heat production in the newborn guinea pig, almost totally disappears within 4 weeks, if the animals are reared at neutral temperature $\left(30^{\circ}\right.$ to $\left.32^{\circ} \mathrm{C}\right)$. By rearing the animals in a cold environment this process can be considerably retarded, but it cannot be entirely inhibited. It is thus suggested that the reduction of non-shivering thermogenesis, as observed during postnatal development, is to be thought of as a developmental process, which is modified by the environmental temperature.

One might infer from the foregoing that the ability to regain non-shivering thermogenesis by cold-adaptation is gradually reduced with increasing age. All the studies on cold-adaptation in adult subjects available so far would be in accordance with this concept. Thus the maximum increase in oxygen uptake that was not explained by shivering did not account for more than $80 \%$ of the BMR in the unanesthetized cold-adapted rat exposed to an ambient temperature of $6^{\circ} \mathrm{C}$ (Har'T, Heroux \& Depocas 1956, Hsieh, Carson \& Gray 1957).

In the human adult the evokation of non-shivering thermogenesis by coldadaptation has been demonstrated by DAvis and by Jox; the exact amount of nonshivering thermogenesis has not been given, but it is obvious that its extent remains far below that found in the cold-adapted rat. The most extreme case of cold-adaptation in a human being was described by PUGH (1963). He studied a Nepalese pilgrim who had survived, uninjured, 4 days of exposure at 15,000 to $17,500 \mathrm{ft}$ in midwinter, wearing only light clothing and no shoes or gloves. In a test study, oxygen uptake was increased by $35 \%$ without visible shivering; with more severe cooling, shivering occurred and oxygen uptake rose to 2.7 times the calculated basal metabolic rate. In contrast, newborn infants increase their oxygen uptake on slight cooling $\left(23^{\circ} \mathrm{C}\right)$ by the same rate without visible shivering (BRüCK 1961, BrüCK, BRǘcK \& LEMTTS 1958).

As for the mass of multilocular adipose tissue, there also exist - again in favour of the neonate - considerable differences between the newborn stage on the one hand, and the cold-adapted adult subject on the other hand. According to the studies of SMTTH \& RoBERTS (1964) the total mass of multilocular adipose tissue in the coldadapted rat amounts to 1.0 to $1.5 \%$ of the body weight. As already reported, in our newborn guinea pigs the interscapular fat tissue alone made up as much as 2 to $2.5 \%$ of the body weight, and the total mass was estimated to be about $5 \%$; in the newborn rabbit, which was studied by DAwKINs \& HULL 1964, the interscapular and cervical adipose tissue makes up as much as $5 \%$ on the average. The different capacity for non-shivering thermogenesis in the neonatal stage and in the adult cold-adapted organism might thus be simply ascribed to the difference in the mass of multilocular adipose tissue. Our results, according to which both the mass of the interscapular multilocular adipose tissue and the non-shivering thermogenetic capacity were reduced 
in the animals kept at $8^{\circ} \mathrm{C}$ (cf. Fig. 3), would fit in with this concept. This inability either to maintain a larger mass of multilocular adipose tissue or to reconvert a sufficient mass of white fat into brown fat might thus be taken as the key for an understanding of the superiority of the neonate even over the cold-adapted adult subject in regard to non-shivering thermogenetic capacity.

As has been previously shown (BRücK \& WüNNENBERG 1965b), the temperature in the interscapular adipose tissue and oxygen uptake begin to increase immediately after external cooling, i. e. non-shivering thermogenesis is presumably evoked by stimulation of the cutaneous thermal receptors. Shivering, on the other hand, does not set in until the core temperature has fallen by a certain amount, indicating that it is presumably elicited by thermosensitive structures that are localized in the body core. Besides the wellknown thermosensitive structures of the hypothalamus, it has been suggested that such structures are localized in the spinal cord (Rautenberg, Simon \& Thauer 1963, Simon, Rautenberg, Thauer \& Iriki 1964). Smith \& Roberts (1964) on the other hand, showed that the venous blood of the interscapular and cervical adipose tissue is drained partly into the inner vertebral sinus, whereby the heat derived from these sources is applied to the spinal cord. One may thus assume that in the newborn guinea pig the temperature of the spinal cord is maintained above the shivering threshold by the heat supplied from the interscapular and cervical adipose tissue. The loss of the thermogenetic function of this tissue might thus be considered as the direct cause of the appearance of shivering during postnatal development. In some preliminary studies (BRÜCK \& WüNNENBERG, unpublished) in which the subarachnoidal temperature of the cervical cord was measured, it was actually demonstrated that in the coldexposed newborn guinea pig, the temperature of the cervical spinal cord is kept at a higher level than colon temperature and even brain temperature and that this temperature sharply drops following the administration of Alderlin, which induces shivering in the newborn guinea pig.

\section{SUMMARY}

1. Cold-induced heat production, its mechanisms and modifications during postnatal development, has been studied in the guinea pig.

2. In the newborn guinea pig, exposed to a test temperature of $8^{\circ} \mathrm{C}$, non-shivering thermogenesis (NST) accounts for at least $90 \%$ of the total cold-induced heat production; the latter makes up as much as 3 to 4 times basal metabolic rate and is sufficient to maintain colon temperature at the normal level of $39^{\circ} \mathrm{C}$. After blockade of NST the animals displayed vigorous shivering, i. e. the shivering mechanism is already developed at the time of birth but is not used under normal conditions. The heat-forming capacity of the non-shivering mechanism is much larger than that of the shivering.

3. At the age of 4 weeks the proportion of NST was less than 10 to $15 \%$ in guinea pigs which had been reared in a warm environment $\left(30^{\circ} \mathrm{C}\right)$, whereas in animals reared in the cold $\left(8^{\circ} \mathrm{C}\right)$, it still amounted to $50 \%$.

4. The newborn guinea pig possesses a large amount of multilocular adipose tissue 
("brown fat"), which is an important site of NST. The multilocular structure in the interscapular fat pad was still present at the age of four weeks in the animals reared in the cold, whereas it had acquired the appearance of white fat in the animals reared in the warmth. Its percentage weight, however, was smaller in the "cold" group than in the newborn group.

5. According to these results, the process of replacement of non-shivering by shivering thermogenesis during postnatal development is to be thought of as a developmental process that can be retarded but not entirely inhibited by cold environmental conditions.

\section{LITERATURE CITED}

BRÜck, K., 1961. Temperature regulation in the newborn infant. Biologia Neonat. 3, 65-119. - 1963. Chemische Thermogenese ("non-shivering heat production") beim neugeborenen Meerschweinchen. Pflïgers Arch. ges. Pbysiol. 278, 58.

- 1964. General aspects of temperature regulation of small subjects. In: The adaptation of the newborn infant to extrauterine life. Ed. by J. H. P. Jonxis, H. K. A. Visser \& J. A. Troelstra. Stenfert Kroese, Leiden, 229-247.

- BRÜCK, M. \& LEMTIS, H., 1958. Thermoregulatorische Veränderungen des Energiestoffwechsels bei reifen Neugeborenen. Pflügers Arch. ges. Physiol. 267, 382-391.

- \& WÜnnenberg, B., 1965a. Uber die Modi der Thermogenese beim neugeborenen Warmblüter. Pflügers Arch. ges. Physiol. 282, 362-375.

- \& WÜNNENBERG, B., 1965b. Blockade der chemischen Thermogenese und Auslösung von Muskelzittern durch Adrenolytica und Ganglienblockade beim neugeborenen Meerschweinchen. Pfügers Arch. ges. Physiol. 282, 376-389.

- \& WÜNNENBERG, B., 1965c. Untersuchungen über die Bedeutung des multilokulären Fettgewebes für die Thermogenese des neugeborenen Meerschweinchens. Pflügers Arch. ges. Pbysiol. 283, 1-16.

Davis, T. R. A., 1961. Chamber cold acclimatization in man. J. appl. Physiol. 16, 1011-1015.

Dawkins, M. J. R. \& Hull, D., 1963. Brown fat and the response of the new-born rabbit to cold. J. Physiol., Lond. 169, 101 P.

- \& Hull, D., 1964. Brown adipose tissue and the response of new-born rabbits to cold. J. Physiol., Lond. 172, 216-238.

- \& Scopes, J. W., 1965. Non-shivering thermogenesis and brown adipose tissue in the human newborn infant. Nature, Lond. 206, 201-202.

Golenhofen, K., Hensel, H. \& HirdebrandT, G., 1963. Durchblutungsmessung mit Wärmeleitelementen. Thieme, Stuttgart, $123 \mathrm{pp}$.

Hart, J. S., Heroux, O. \& Depocas, F., 1956. Cold acclimation and the electromyogram of unanesthetized rats. J. appl. Physiol. 9, 404-408.

Hsien, A. C. L., Carison, L. D. \& Gray, G., 1957. Role of the sympathetic nervous system in the control of chemical regulation of heat production. Am. J. Physiol. 190, 247-251.

Joy, R. J. T., 1963. Responses of cold-acclimatized men to infused norepinephrine. J. appl. Physiol. 18, 1209-1212.

Karlberg, P., Moore, R. E. \& Oliver, JR., T. K., 1962. The thermogenic response of the newborn infant to noradrenaline. Acta paediat., Stockh. 51, 284-292.

MOORE, R. E. \& UNDER wOOD, M. C., 1962. Hexamethonium, hypoxia and heat production in new-born and infant kittens and puppies. J. Physiol., Lond. 161, 30-53.

- \& UNDER WOOD, M. C., 1963. The thermogenic effects of noradrenaline in new-born and infant kittens and other small mammals. A possible hormonal mechanism in the control of heat production. I. Pbysiol., Lond. 168, 290-317.

MoRdHoRst, H., 1933. Uber die chemische Wärmeregulation frühgeborener Säuglinge. Mscbr. Kinderbeilk. 55, 174-191. 
Pugr, L. G. C. E., 1963. Tolerance to extreme cold at altitude in a Nepalese pilgrim. J. appl. Physiol. 18, 1234-1238.

Rautenberg, W., Simon, E. \& Thauer, R., 1963. Die Bedeutung der Kerntemperatur für die chemische Temperaturregulation beim Hund in leichter Narkose. Pfingers Arch. ges. Physiol. 278, 337-349.

SCOPES, J. W. \& TIZARD, J. P. M., 1963. The effect of intravenous noradrenaline on the oxygen consumption of new-born mammals. J. Physiol., Lond. 165, 305-326.

Simon, E., Rautenberg, W., Thauer, R. \& Iriki, M., 1964. Die Auslösung von Kältezittern durch lokale KKühlung im Wirbelkanal. Pfiugers Arch. ges. Physiol. 281, 309-331.

SMith, R. E. \& Hock, R. J., 1963. Brown fat: thermogenic effector of arousal. in hibernators. Science, N.Y. 140, 199-200.

- \& RoBerts, J. C., 1964. Thermogenesis of brown adipose tissue in cold-acclimated rats. Am. J. Pbysiol. 206, 143-148.

\section{Discussion following the paper by BRÜCK \& WÜNNENBERG}

MARMASSE: Which technique did you use to measure hypothalamus temperature? I would like to point out that the absence of blood collection at the tip of the transducer - be it a thermistor or a thermocouple - is important, since such a collection can introduce an important time-lag.

Brück: Time lag is very small with the thermocouples used in our experiments since the diameter of the wires used was only $0.1 \mathrm{~mm}$.

MARMasse: Early experimenters claimed that the temperature of aortic blood was more constant than coelomic temperature. If this is verified, it could be most useful for experiments such as yours.

BRÜCK: In small animals even the aortic temperature will change considerably. We were not up to find a site of particular temperature stability since we wanted to know the regulatory reactions occurring with changes in environment and body temperature.

Donhoffer: Haben Sie neben der elektrischen Aktivität des Muskels auch gleichzeitig seine Temperatur gemessen?

BRÜck: Nein, wir haben die Muskeltemperatur nicht gemessen.

ZEISBERGER: In spite of the special type of non-shivering thermogenesis stimulated by noradrenaline developing during acclimation to cold, it seems that some other types of non-shivering heat production also exist. I have noticed in some pictures which Dr. Brück showed us that there was a difference between the level of oxygen consumption in cold-acclimated animals after blocking their $\beta$-receptors, and between warm-acclimated ones. Could this difference not prove such a possibility?

BRÜCK: There are two factors that are to be considered as to the differences which you have mentioned: (1) the basal oxygen uptake (as measured at neutral temperature) is larger in the cold-adapted animals; (2) the increment of oxygen uptake in relation to shivering (electrical activity) is larger in the animals reared in the cold; the latter difference might be attributed to some non-shivering thermogenesis not blocked by Alderlin, which would be in favour of your assumption. Alternatively, however, one has to think of the possibility that the shivering mechanism is more effective in cold-adapted animals; in other words, oxygen uptake per muscle twitch might be larger in the cold- than in the warm-adapted animal. 